\title{
THE UZBEK MODEL OF BIOETHICS: HISTORY AND MODERNITY
}

\author{
MUKHAMEDOVA ZAMIRA MUKHAMEDZHANOVNA*, UMIRZAKOVA NARGIZA \\ AKMALOVNA \& MAKHMUDOVA AZIZA NUGMANOVNA
}

\begin{abstract}
Modern biomedical ethics is based on a rich tradition of systematic moral thought, both philosophical and religious. In the XXI century, the interaction and synthesis of natural and humanitarian disciplines are of paramount importance in the system of biomedical education. One of the ways to solve this problem for future specialists is to study the foundations of biomedical ethics, the formation of a bioethical culture of future doctors. Among the ancient scientists of Central Asia who became famous in the field of medicine and pharmacy, a prominent place is occupied by Abuali Ibn Sino (Avicenna), whose life and work can serve as an example of national and historical identity, patriotic education of the youth of Uzbekistan. The emergence of such a phenomenon as the "Muslim Renaissance" and in this context the life and work of Avicenna, his role in the history of the development of medicine in Uzbekistan, are devoted to many, which, like others, were included in the materials of this study. A kind of bridge from ancient medicine to the medicine of the Renaissance and further to modern medicine was the legacy of doctors in Central Asia and Arab physicians. At present, the social, legal and economic aspects of ethical problems of key issues of bioethics in the field of health, medicine and biomedical technologies in the context of the Islamic faith continue to be studied.
\end{abstract}

Keywords: Muslim renaissance; Abu Ali Husain ibn Abdullah ibn al-Hasan ibn Ali ibn Sina; Medical ethics; Bioethics Muslim; Key Muslim bioethics issues

\section{INTRODUCTION}

A huge role in the development of Islamic global bioethics should be noted: we are talking about the value of scientific, medical and philosophical legacy of the Arabic scientists from the East and Central Asia. A clear awareness of this historical fact is the creation of the Avicenna Prize by the UNESCO Executive Board in 2004, the proclamation of the city of Tashkent as one of the capitals of Islamic culture in 2007, and the recognition of Bukhara as the capital of Islamic culture in 2020. On the territory of Uzbekistan, medical science was formed and received the highest development during the Middle Ages (X-XII centuries). The life and work of outstanding medical scientists of medieval Uzbekistan belong to this time. Among them, the leading place is occupied by the famous scientist and doctor Abu Ali ibn Sina (Avicenna). He is the founder of scientific medicine in Central Asia (Kadyrov 1994). Other well-known medieval medical scientists, such as Sharafutdin ibn Abdullah Ilokiy, Ismail Jurjaniy, Mahmud ibn Umar Chagminiy, Najibuddin Samarkandiy, Abu Sahl Masihiy and others, also played a significant role in the creation and development of scientific medicine in Uzbekistan.

The United Nations Educational, Scientific and Cultural Organization (UNESCO), on the occasion of the 1000th anniversary of the creation of the encyclopaedic work "Canon of Medicine", declared 2013 the Year of the great scientist of the Muslim world - Avicenna. Abu Ali Hussein ibn Abdullah ibn al-Hasan ibn Ali ibn Sina: "an encyclopaedist, philosopher, 
physician, mathematician, astronomer - the most famous scientist of Islam" (Sarton 1927). A huge number of books and conferences have been devoted to his works, dissertations have been written, his works are carefully preserved in various libraries of the world. In Tashkent, in the funds of archival institutions, particularly in the Central sovereigns governmental archive of scientific, technical and medical documentation at the Institute of Oriental Studies of the Academy of Sciences of Uzbekistan materials and manuscripts are stored, showing the history of the development of medicine in Uzbekistan. Medical period of Arab Caliphate (early Middle Ages) was created not only by the Arabs but also the local medical scientists.

At the end of the 9th century, Central Asia was liberated from Arab reign, and several independent states were formed on its territory. Khorezm became one of the developed states of the East. Culture and science achieved particular prosperity during the reign of Mamun ibn Mamun (early 11th century). The scientists, who lived in the palace of the Khorezmshah, were united in the "Majlisi Ulamo" ("Assembly of Scientists"), known in history under the name "Academy Mamun". The great Uzbek scientist Abu Raikhan Beruniy was in charge of the "Academy". The "Academy" consisted of scientists - specialists in many aspects of Sciences, including experienced governors. The list of members of the academy included doctors such as Abu Ali Ibn Sina, Abu Sahl Masihiy, Sharafuddin ibn Abdullah Ilokiy, Abu Mansoor Qamar and Abul Khair Hammar. In Khorezm, in particular, in Urgench, doctors from other countries lived and worked. Hospitals, clinics, pharmacies and other institutions were built in Urgench and other cities, where experienced doctors and pharmacists worked. Abu Ali ibn Sina, as well as Abu Sahl Masihiy and a disciple of Ibn Sina Ibn Abdullo Ilokiy, worked at Urgench hospital for some time. Not only did they treat patients, but also they conducted an observation of certain diseases, summarized obtained data, developed new methods of diagnosis and treatment. The history of the development of scientific medicine in Central Asia (Uzbekistan) is associated with the name of another prominent scientist of the Middle Ages - Abu Bakr al-Raziy. He was originally from Iran but made a significant contribution to the development of medicine in Central Asia. For some time Raziy lived in Central Asia, in Bukhara and Khorasan, communicated with local scientists. In Khorasan, Raziy served as a physician-in-chief of the ruler Abu Salih Mansur ibn Ishaq. Here he wrote his famous medical treatise "Kitab at-tib alMansuri" ("Medical book dedicated to Mansur"). In Central Asia and Khorasan, Razi studied the achievements of sciences and cultures of the peoples of the two countries and made a certain contribution to their development. Here he prepared several students such as Muhammad ibn Yunus - later a prominent scientist (Kadyrov 1994).

\section{METHODS}

The methodological basis is historical and comparative analysis. This study examined the ancient sources of bioethics in Islam, which included the knowledge of practical ethics of alRuhavi (Ishaq ibn Ali al-Ruhavi) "Adab al-Tabib", "Canon of medical science" Avicenna and Akhlaq Al Tabib Ar-Razi, and many others, has become a model of classic in the annals of medical ethics continue to shape the spiritual basis of the Islamic medical code, bioethics, environmental and biomedical ethics. This study shows the role of fundamental methodological sources of the Uzbek model of bioethics. Among the ancient scientists of Central Asia who became famous in the field of medicine and pharmacy, a prominent place is occupied by Abumansur Muwaffak Aliya Khirawi and Abuali Ibn Sino (Avicenna), whose life and work can serve as an example of national and historical self-awareness, patriotic education of the youth of Uzbekistan. The emergence of such a phenomenon as "Muslim Renaissance" and in this context, the life and work of Avicenna, his role in the history of the development of 
medicine in Uzbekistan many of the works (Abdullaev 1980; Kadyrov 1990, 1994; Makhmudova 1969) were included in the materials of this study.

\section{RESULTS AND DISCUSSION}

\section{History of bioethics in Uzbekistan}

Back in the 9th century, the physician Ishaq bin al-Rukhawi wrote the first treatise on medical ethics - Adab al-Tabib. In this treatise, Rukhavi calls doctors "keepers of the soul and body," observes and analyses the behaviour and deeds of a Muslim doctor (Zikria 1967). Al Ruhavi completed a lot in his work, to "humanize" the medicine, given the problems of mutual relations with patients. He believes that the goal of the doctor is to bring good and well-being. Adab al Tabib is an excellent illustration of the professional responsibility and ethical dilemmas that are still relevant in medicine today.

Ahlak al-Tabib - the work of Abu Bakr Muhammad ibn Zakariyah Ar Razi, who received the title of Galen of the Arabs, is undoubtedly one of the most outstanding achievements of medicine. The work, written during the Eastern Renaissance, can serve as guiding principles not only to enrich the theory of bioethics but also serve as a guide to action and function as a mechanism for the humanization of modern medicine and healthcare. The bioethical foundation embedded in it, in which medicine and a dignified lifestyle form a single philosophy of health, has not lost its relevance today. Abu Mansur Kamariy and Ibn an-Natiliy are known from the Bukhara tabibs of antiquity. Abu Mansur Kamariy (Kumariy) known as Abu Mansur Bukhariy. His full name is Abu Mansur Hasan ibn Nuh al Kamariy. Historians point out that Kamariy was the first teacher of Ibn Sina in medicine, instilled in him the love for medicine. Kamariy was well acquainted with the works of ancient Greek, Roman, Indian, Byzantine medical scientists. The works of Abu Mansur Kamariy played a significant role in the development of scientific medicine in Uzbekistan.

There are reliable facts among medieval sources that Abu Raikhan Biruni and Abu Ali ibn Sina met in Gurganj in 1004. Together with al Biruni, he was engaged in the development of chemistry here. Biruni proved the connection between the comparative mass of a substance and its chemical composition in his work on "Comparative Mass". Ibn Sina carried out chemical experiments on the transformation of substances, and these results were described in the work "Treatise on the Philosopher's Stone". This article was written in Gurganj in 1005 (Kadyrov 1969). Medicine was of particular interest at the Mamun Academy. Abu Khair Hammor was known as the Second Hippocrates for his advanced theories in the areas of human anatomy, diet for the elderly, methods of medical experimentation, nutrition and epilepsy. Abu Sahl al-Masihi became famous for his medical practice and teaching. Ibn Sina himself during this period wrote several works on the treatment of wounds, and also got the opportunity to conduct regular clinical activities and collected a huge amount of material for writing his future works - "al-Qanun fi-t-tibb" and "al-Kitab-ash-shifa" (Kadyrov 1969). The historical research of the academy is known thanks to the "History of Khorezm" and "India" by al Biruni. Unfortunately, the first of these books has not survived, but a significant part of it has survived in the work of Abu Fazil Bayhahi "History of Masudi", which was dedicated to Sultan Masud Ghaznavi. According to numerous testimonies, "Mamun Academy" enjoyed the fame of the center of literature and art. Known poets and writers worked here: Ahmad bin Muhammad bin Sakhr Abdullah bin Hamid, Abu Saeed bin Shabib, Abu Hassan ibn Mamun, Abu Abdullah alTohir Ibrahim Rakkoni (Kadyrov 1969). 


\section{The Canon of Medicine}

Equipping a doctor with knowledge about the laws and principles of transforming the spiritual principle in a person, Ar-Raziy and Ibn Sina created a philosophical basis for the behavioral standards of both a doctor and a dying patient. According to historical records, the "Canon of Medicine" is one of the most famous and widespread sources of medical practice and research in scientific and medical centers both in the East and in the West. The author of this book, thanks to his genius, was able to collect and systematize the entire spectrum of medical knowledge in it, and also added many new things to it. Avicenna brought together in one book the main issues in the field of medicine, his work was of interest to both doctors and students. Avicenna insistently emphasized that medicine is a science and medical knowledge should be organized in a rigorous scientific way. Due to this position of Avicenna, the treatment of patients acquired a scientific coloration, as a result of which the way to superstition and magic was closed.

Life and its safety have always been at the center of Muslim religious and cultural teachings based on the Koran, Hadith and Shariah. In Islam, human life is viewed as an invaluable gift from God and therefore must be respected and protected. For thousands of years the problem of human knowledge, the specifics of his life and creative and constructive activities attracted the attention of scientists from different fields of knowledge. As a result of what particular features does Avicenna's book "The Canon of Medicine" enjoy such historical popularity? Let us mark several features of the "Canon of Medicine", which enhance the scientific credibility of this book. 1. "The Canon of Medicine" is not only a book of recommendations used for the treatment of patients, but also a textbook developed according to the specific principles of scientific planning of medical education. As it is known, textbook compilation is a separate activity with its own rules and principles. The Canon of Medicine is, in this sense, a technically well-written teaching material. The book is written in 5 volumes, each of which is devoted to one main topic. The following issues are discussed, which even today in the curricula of medical universities sometimes do not receive due attention: sleep and wakefulness, water, air, living conditions, exercise, change of environment and other factors that have a significant impact on human health , hygiene and education of children . Today, despite all the advances in modern medicine, it is possible to note that "Canon" by Avicenna is useful to mankind, as it is an example of high-quality materials of the scientific organization and systematization of medical knowledge relying on the laws of nature.

In the teachings of Avicenna, the ideas of such ancient Greek philosophers, scientists and doctors as Aristotle, Hippocrates and Galen were further developed, their teachings were combined with his own original ideas, which, in turn, had a great influence on the subsequent development of philosophy, science and medicine as the East and the West. Ethical issues take a lot of place in Avicenna's writings. Ibn Sina divides practical philosophy into three components, each of which deals with the "dispensation of man" in accordance with his purpose. So, the first part of Ibn Sina is devoted to ethics, or, as he calls it, "Education of morality" (Tahzibi ahlok). According to it, "a person should know what morality he will acquire, what traits he should be endowed with and what actions he should perform in order to achieve happiness in earthly and in the higher life." The scientist believes that Aristotle's book "Nicomachean Ethics" can become the best guide in this (Rakhimov 1979). Author of many works on medicine, philosophy, as well as poetry, most of which are written in the form of rubai. Ibn Sina also developed his own teaching on the temperament and character of a person - the theory of mizaj. Ibn-Sina, the creator of the "Canon of Medical Science, considering various aspects of medical activity, emphasized the uniqueness and individuality of those seeking medical care:"... Each individual person has a special nature inherent in him personally" (Ibn Sina 1985). In his famous "Canon of Medicine", he presents the art of 
medicine as an integral theoretical and practical knowledge, focusing on the integral vision of man as a spiritual-bodily being. The Ibn-Sina's treatise is characterized by an emphasis on the humanitarian, psychological and moral aspects of healing. One of the main ideas of the "Canon of Medicine" is the need to prevent disease, which should be the focus of the efforts of the doctor and the patient. According to his teachings, human nature is divided into four simple types: hot, cold, wet and dry (which in modern psychology corresponds to four temperaments). These natures are not stable, but change under the influence of internal and external factors, such as meteorological conditions and the change of seasons. Changes in body fluids can also correct nature in the appropriate direction. In addition to simple natures, Avicenna distinguished four more complex natures, depending on the prevalence of one of the four body fluids (blood, mucus, yellow or black bile). "Canon of Medicine" in 5 books, which is a synthesis of ancient, Indian and Central Asian medicine based on the canons of Islam. The theoretical basis of this work is the Galen's system, which made it equally in demand both in the countries of Islam and later in European universities. The first book of the "Canon" covers the theory of medicine (anatomy and physiology), as well as the principles of hygiene: proper nutrition, physical activity, water procedures. Ibn Sina emphasizes the hygiene of children, pregnant women, elderly people (vulnerable groups of the population in modern language). The physiological concepts of Ibn Sina are based on the humoral theory and the doctrine of temperaments (mizaj). The 2nd and 5th books are devoted to medicine: the 2nd - to simple medicines, and the 5th - to "complex" medicines, poisons and antidotes. The "Canon" describes more than 800 medicines with an indication of their action, methods of use, collection and storage rules. Ibn Sina played an important role in the development of the science of medicine: he formulated the basic principles of drug testing, including experiments on animals and observation at the patient's bed; described the possibility of interaction of several drugs and possible side effects, as well as the chemical methods for their preparation . "Do you know," the thinker asked, "what generosity is?" (Abu Ali Ibn Sina, p. 401). And he himself answered: "Generosity is bringing the necessary benefit without any reward ... The one who shows generosity for the sake of glory, praise for what he has done is a self-interested person, not generous. Truly generous is the one who benefits without any intent, does not have the deliberate goal of compensating them" (Abu Ali Ibn Sina, p. 401).

\section{The Poem of Medicine}

Canon of Medicine, an encyclopaedic collection of medical knowledge, is devoted to preventive measures aimed at preventing diseases, their diagnosis and treatment. It contains not only the views of ancient Greek, Roman, Indian, Arab doctors and philosophers, but also theoretical knowledge and experience of Avicenna's healing. And therefore, Avicenna's work was not only a new stage in the development of medicine, but also a program of action for subsequent generations of doctors. "The Poem of Medicine" ("Urdzhuza") is a medical treatise, which experts give the second most important place after the "Canon of Medicine". The treatise examines elements of medical ethics and deontology ("A patient who just got out of bed barely resembles himself ... A doctor, remember, prescribing something, be attentive to him ... Surround him with generous care, choose words wisely. Come in with a kind smile to him ... Assign everything with special attention, Keep an eye on the state of the body").

In the "Poem about Medicine", in the 257th work, the author explains the natural components and elements of nature, male and female mizaj, age ("Hot in childhood, in youth, like a flame, He becomes colder over the years. In his works, Avicenna is very careful about medicine prescription. Avicenna requires the doctor to clearly understand why he is prescribing this and not another medicine ("Take into account the mizaj, the color of the skin and the age of the patient, too. Everything is important: the place of residence, nature, 
Civilization and the season. Study everything ... Be careful in prescribing each. The disease should be wisely distinguished"). Avicenna paid special attention to the need for an individual approach to each patient, since "each individual person is predisposed to a certain nature inherent in him personally" And recommended to individualize medicinal prescriptions for patients. Avicenna considered age to be very important in the approach to the patient, specific characteristics of patients, seasons, influencing the occurrence of certain diseases and their course in patients, as well as concomitant diseases in a particular patient. This fundamental and basic requirement, which left its mark on the entire system of medical knowledge of Avicenna, and now, after many centuries, retains its significance in medicine.

\section{Ethics and morality}

The scientist was also concerned with other ethical issues. The contribution of Avicenna to the development of medical problems, to helping people to recover from diseases, and original methods for keeping fit was recognized. Avicenna was the first to raise to the level of theoretical comprehension the problem of the importance for a doctor of a correct philosophical understanding of the essence of nature. Unlike other medical practitioners, he considered this kind of knowledge to be overly important for medical practice. It is philosophy (metaphysics) that provides systemic knowledge about nature, outside of which a person cannot exist, and this cannot be ignored in the process of making a diagnosis and prescribing methods for treating a patient. At the same time, he warned doctors about the danger that awaited them here and considered it unacceptable for them to deal directly with the problems of metaphysics. Philosophy, that is, first wisdom, should deal with these problems. "When one of those claiming to be a doctor begins and starts to reason, proving the existence of elements, natures and what follows them and is the subject of the science of nature," noted Avicenna, "he makes a mistake, since he introduces that he does not belong to the art of medicine. He is also mistaken in the sense that he believes that he has explained something, while he did not explain it at all" (Abu Ali ibn Sina, p. 83). It is enough for a doctor to be guided in the field of philosophy by generally accepted things, that is, by the provisions established by "experts in science." As for medical issues, methods of healing, here the doctor is obliged to get to the bottom of the truth on his own.

The fundamental ideological basis of Avicenna's work is the principle of "do no harm", which was used by doctors of antiquity before. It expresses the humanistic ideals of healing, the attitude towards the patient's life as a value, manifests itself in the feelings of the doctor's compassion for the patient and is realized in acts of their assistance, complicity and assistance. Compliance with the principle "do no harm" is also expressed in the moral responsibility of the doctor, both in relation to an individual patient and a group of patients. Avicenna put forward as an important, obligatory condition the placement of patients with infectious diseases in the hospital. He substantiated this requirement by the need to limit the spread of the disease, to study the course of the disease, to find the most reliable means for cure. The humanistic ideals of Avicenna's "Canon of Medicine" anticipated the operation of moral principles in medicine today: the principle of the autonomy of the doctor and the patient, the principle of their informed consent, the principles of social responsibility and justice.

"The basic moral idea that permeates the entire Canon is the idea of humanism. It is stated starting from the first provision of the "Canon", in which the tasks of medicine are formulated. "I affirm: medicine is the science of knowing the state of the human body, since it is healthy or has lost health in order to maintain health or restore it if it is lost" (Abu Ali ibn Sina 1981). Avicenna attached great importance to the need to calm the patient down, remove the feeling of fear, and raise his mood. Avicenna, considering various aspects of medical practice, emphasized the uniqueness and individuality of those seeking medical care: "... each 
individual person has a special nature inherent in him personally. It rarely happens or it is completely impossible for someone to have the same nature" (Abu Ali ibn Sina 1981). The word is of great importance, which implies not only the culture of speech, but also a sense of tact, the ability to raise the patient's mood, not to hurt him by careless statements. It is not for nothing that the great scientist said: "There are three means to cure a sick person: with the help of words, medicines made from herbs, and the third means - a knife" (Grando 1994).

In the Middle Ages, Avicenna gave an excellent poetic description of the personality of a doctor. He believed that a doctor should have special physical and spiritual qualities - the eyes of a falcon, the hands of a girl, the wisdom of a snake and the heart of a lion. In the writings of Ibn Sina there are recommendations: "... let pregnant women avoid too abrupt movements, jumping and falling, hitting, ... as well as overflowing with food and anger. They should not tell them what grieves them, and should be removed from them all that contributes to miscarriage ... ". "The recovering person must be protected from everything that excites, even from loud sounds. He should be kept in peace, amused and gladdened ... ". He advised patients to walk "as much as they like, excluding all thoughts of business," prescribed peace, a serene state of mind, silence, and suggested to patients with tuberculosis that "they should constantly smell flowers and lie all the time, staying at rest and immobility, and avoid anger and irritation. ... They should not be told sad news ..." (Abu Ali ibn Sina 1981). Avicenna's ethical legacy has not lost its significance, and today, on the contrary, it is gaining special relevance. It is successfully used in the moral education of the younger generation, and this task, as we know, never loses its relevance.

In the course of studying the philosophy, Av and Val became a follower of the teachings of Aristotle. He developed his own view and created his own aesthetic and ethical teachings. In his "Ethics" he considered constant self-improvement as the main thing. And he recognized as the highest law of human behaviour not the concepts, laws and categories of ethics in themselves, but how they are evaluated by reason, which for Avicenna is the criterion of morality and the prerequisite for human relations based on good and justice. He defined ethics as a science that theoretically distinguishes between the principles of good and evil and provides conditions for human happiness. Good, as Avicenna believed, is the innate tendency of a person to perfection. It is this tendency, according to Avicenna, that "encourages a person to do good deeds" (Abuali Ibn Sina 1976). Good is an attribute of the essence of man, which is rooted in matter itself since it is inherent in the desire for improvement. Thus, good is an attribute of matter, and evil is associated with nothingness (dark forces of nature), which stops a person's movement towards perfection, is a kind of brake. In human actions, good and evil are mixed in such a way that good deeds often lead to evil consequences and vice versa. But in life, knowledge of both is necessary. Therefore, the connection between good and evil is a measure. For example, good food, getting pleasure is good, but they can lead to evil - loss of health. The true measure of good and evil in human actions, according to Avicenna, is determined by moderation in desires and fairness in decisions: "... a reasonable regimen in food and drinks, the choice of suitable air, the choice of movement and rest, as well as medication and hand action, leading to the preservation of health, and the treatment of each disease separately. From the point of view of the ultimate goal of this research, that is, preserving health and ending disease, [medicine] must also have objects; according to the means and tools [used] in these conditions. The means here are the expedient use of food and drinks, the correct choice of air, the determination of the measure of rest and movement" (Abu Ali ibn Sina 1981). Avicenna did not consider morality to be a social institution that regulates human relationships - the way we understand it today. Nevertheless, his ethical teaching is characterized by a call for deeply moral relations between people, condemnation of moral vices, belief in the possibility of common happiness and good and the desire to achieve them, which undoubtedly speaks of the humane position of Avicenna's worldview. Avicenna's medical practice was a 
manifestation of this position in life. The ethical views of Avicenna as a physician regarding the relationship between a doctor and a patient can be considered in Avicenna's reasoning regarding the definition of the patient's condition. "The term "health" is inapplicable to him because health is an ability or state due to which the functions (of the organ) intended for their fulfilment are impeccable, but the opposite term is not appropriate for it either, unless you define health as you like, conditioning it with unnecessary conditions. Do not argue about this with doctors, and doctors are not the kind of people with whom they argue about such things. Such altercations with doctors or with those who argue with them, do not lead to anything useful in medicine ..." (Abu Ali ibn Sina 1981). The idea of the doctor's impeccability, expressed by Hippocrates, is further developed in the writings of Avicenna. Avicenna calls on doctors "... to improve general and special knowledge, exchange experience, travel. As for those things that a doctor is obliged to imagine and prove, these are diseases, their particular causes, their symptoms, as well as how to stop the disease and maintain health. The doctor is obliged to provide evidence [of the existence] of those of these things that exist latently, in full detail, indicating their magnitude and frequency" (Yuldashev 1980, p. 168). The thought of maintaining health is an integral part of Avicenna's entire system of views and recommendations. According to him, a doctor is a friend, mentor and assistant to the patient. To fulfil this mission, in addition to professional knowledge and experience, he must have many positive qualities: mercy, respect for human dignity, readiness for self-sacrifice in the interests of the patient, and others. To see in each person a unique world of his experiences, passions and hopes. He called to treat not the disease, but the patient. Providing assistance on bioethical (socio-psychological grounds) Avicenna can be seen if necessary instructions for the patient. "So, for example, in medicine they say that the number of types of fever is three and that there are, for example, nine natures. And by practice in medicine, we mean not (only physical) action and the production of somebody movements, but also that part of medical science, the teaching of which concludes with useful advice, and that advice is connected with the presentation of the essence of any procedure. So, for example, in medicine it is said that something distracting, cooling and opening should be applied to hot tumours; then, after that, the distracting agents are mixed with emollients, and after it comes to falling off, they are limited to emollient and accelerating drugs, but not with tumours formed from bad juices secreted by the dominant organs. Such instruction gives you useful advice, that is, a statement of the essence and essence of any procedure. When you study both of these parts, you will acquire scientific knowledge and practical knowledge, even if you yourself have never practised" (Abdullaev 1980). Avicenna's ideas about the importance of supplementing scientific research with cultural and ethical parameters and humanistic guidelines are very important in modern medicine. Moral and ethical reflection is an integral part of modern medical knowledge. Of particular importance today is the study of the ethical parameters of biomedical knowledge since the new possibilities of medicine and biology allow not only to treat people but also to control human life, its most important processes (birth, death, ageing, etc.). The theory and practice of ethical assessments in the field of biomedical advances, in the practice of the increased technological capabilities of biomedicine, are often subject to pragmatic interests; therefore, it requires steady development. The development of modern biomedicine poses new and extremely complex moral problems for philosophy. Since a person acts as a unity of his natural and social qualities, that is, as a unique given, his research is based on humanitarian approaches and methods underlying the bioethical model. They are often carried over to the problem of life in general, which, as an object of bioethical research, is included in the specifics of human relations and assessments. 
Problems such as the relationship between a doctor and a patient, the problem of determining death and the necessary moral contradictions associated with it, new technologies of childbearing and a biomedical experiment, including the need to consider the limits of its admissibility, ethical problems of genetic engineering, transplantology and psychiatry, are the focus of bioethical reflection. The issue of developing such socio-ethical principles is still relevant, in which the uniqueness and freedom of the individual is recognized, provided by moral and legislative norms and actions on the part of society as a whole in the mainstream of the constructive development of scientific activity, subject to the observance of the appropriate ethical standards of knowledge and practice. Practical application of scientific achievements in health care is a condition for a comprehensive consideration of traditional norms of medical ethics. For example, serious moral difficulties arise in connection with organ transplantation: 1) transplantation of organs and tissues from living persons and corpses (homotransplantation); 2) in the case of transplantation of cells, tissues or organs between individuals of different biological species, for example, transplantation of pig heart valves to humans (xenotransplantation); 3) the possibility of organ transplantation from person to person (allotransplantation); 4) when using electronic computers in clinical medicine; 5) in the work of medical and genetic consultations, and so on (Moral Problems in Medicine 1996). The professional ethics of a doctor is to implement in his activities specific moral requirements and norms of behaviour in relations with patients. Modern biomedical research of a person, decoding of his genome, research of human embryos, genetic research and technologies in their totality problematize such concepts as "human dignity", "human right", "personality", "freedom of choice", "responsibility"...

What do they say about artificial insemination, which method is allowed, and which is considered prohibited? Uzbekistan is a secular state, but Muslims live here, for whom the issues of new biomedical technologies and their solution in the context of Muslim bioethics are relevant. To answer these questions, the head of the fatwas department of the Muslim Board of Uzbekistan Homijon Ishmatbekov took part in the second meeting of the Council of Fatwas of the Eurasian Islamic Union, which took place on December 16-17, 2017 in Istanbul. The agenda of the meeting included issues related to artificial insemination (Centre 12020 ).

Having studied all aspects of this issue, scientists from the Muslims Office of Uzbekistan published a fatwa on artificial insemination.

\footnotetext{
"In recent years in our country, couples, not having the possibility to have children, to keep the family together and raise a child, expressed their desire to turn to the practice of artificial insemination. It became known that some even had a child in this way. It should be noted that the practice of artificial insemination, not knowing the requirements of Sharia and not observing them, leads to some moral, social and religious problems. As indicated in the text of the fatwa, in particular, "opportunities are openness for women who want to have a child without getting married; secondly, the number of children born out of wedlock will increase; thirdly, there may be situations of confusion of ancestors ( origin), not knowing who the child's mother is, and fourthly, trading in fertilized eggs or unfertilized eggs and sperm cells can be a source of income."
}

In view of the above, the Muslims Office of Uzbekistan announces this fact:

1. The use of artificial insemination is permitted only in urgently necessary cases for married couples who have entered into a marriage in accordance with Muslim nikah traditions.

2. During artificial insemination, when storing the sperm of men and women who were married under Sharia law, every precaution must be taken to prevent mixing of other people's sperm. This operation must be performed by a qualified doctor. 
3. Artificial insemination is prohibited for unmarried couples under Sharia law.

4. Muslims who are concerned about preserving the purity of their ancestry should not use prohibited methods of artificial insemination, the document says.

In cases of carrying someone else's child, there can be two cases here:

1. If a woman's ovaries are functioning normally, but she is unable to carry a child, she can take one or more eggs to fertilize them in vitro with her husband's sperm. The resulting embryo is placed in another woman's uterus after 48 hours, who gives birth to a baby after nine months. Since Islam recognizes polygamy, a pregnant mother can be the second wife of her husband, who will donate his sperm to fertilize the egg of the first wife.

2. Islam prohibits this method of childbearing if the egg does not belong to her husband's wife or if the child is carried by a stranger.

Thus, the Muslim religion allows only legal spouses to resort to artificial childbirth with medical intervention and subject to the following conditions:

- it is necessary to know the donor of germ cells in order to exclude incest and ensure legal relationship in accordance with Muslim law;

- mutual voluntary and conscious consent of the legal spouses is required.

\section{CONCLUSION}

Modern biomedical ethics is based on a rich philosophical and religious tradition and maintains a historical continuity with traditional professional medical ethics (Mukhmadova 2015). A kind of bridge from ancient medicine to the medicine of the Renaissance and further to modern medicine was the legacy of doctors in Central Asia and Arab physicians. At present, the social, legal and economic aspects of ethical problems of key issues of bioethics in the field of health, medicine and biomedical technologies in the context of the Islamic faith continue to be studied. Muslim bioethics is developing dynamically. It is not limited solely to the aspect of doctrine but unites and transforms the most important international documents (the Nuremberg Code, the Helsinki Declaration, the Universal Declaration on Bioethics and Human Rights, etc.). Over the past 35 years, such issues of bioethics in Islam as organ and/or tissue transplantation, criteria for brain death, principles of care and technology in the intensive care unit, problems of reproductive technology, cloning, genetic engineering, biotechnology, AIDS, psychiatry, etc. have been considered. We are considering a variety of key issues of bioethics and the rights of a child, pay attention to spiritual development and moral component in the medical education of future doctors. Bioethics becomes an essence of modern moral consciousness as its first kind moral imperative in the life and work of people who should learn to live in harmony with themselves and nature. Arming physician with knowledge of the laws and principles of the transformation of the spiritual principle in man, Ibn Sina created philosophical basis for the behavioural standards for a doctor and a patient. Noting the enduring importance of the ideas of Ibn Sina, and earlier Ar-Razi, in the field of bioethics and necrodeontology, we emphasize that bioethical thinking and deontological practice today, as in past centuries, are inextricably linked with religious and spiritual knowledge, which is in the culture of the peoples of Uzbekistan It is inseparable from the philosophical traditions of the physicians of eastern Renaissance and, above all, Ibn Sina. 


\section{REFERENCES}

Abdullaev, A. A. 1980. Essays on the history of the development of medicine in Khorezm. Tashkent: Medicine.

Abu Ali ibn Sina. 1981. Canon of Medicine: in 5 volumes / Abu Ali ibn Sina. - Tashkent: Publishing house of FAN - T. 1. - 550 p.

Abuali Ibn Sina. 1976. Treatise on Love // Serebryakov S.B. Ibn Sina (Avicenna) 's treatise on love. Tbilisi: Metsniereba.

Zikria, B. A. 1994. Medical Ethics of Medieval Islam with Special Reference to Al-Ruhawi's Practical Ethics of the Physician ", Vol. 57, Part 3.1967 translated by Martin Levey

Grando, A.A. 1994. Medical ethics. - Kiev: RIA "Triumph".

Centre 1. 2020. https://centre1.com/uzbekistan/musulmanam-uzbekistana-razreshiliiskusstvennoe-oplodotvorenie/

Ibn Sina. 1985. Canon of Medicine / Abu Ali ibn Sina. - Tashkent.

Kadyrov A. A. 1990. The emergence of medicine in Central Asia. Tashkent: Medicine.

Kadyrov A.A. 1994. The history of medicine in Uzbekistan. Tashkent: Ibn-Sina.

Makhmudova N.M. 1969. Essays on the history of the development of internal medicine in Uzbekistan. Tashkent: Medicine.

Moral Problems in Medicine. 1996. Englewood Cliffs. - NY.

Mukhamedova Z. M. 2015. Bioethics in Uzbekistan: History, Issues, Prospects Singapore.

Rakhimov, S.R. 1979. Ibn Sina's psychological and pedagogical views. - Tashkent.

George, S. 1927. Introduction to the History of Science. Washington.

Yuldashev, K. Y. 1980. Some therapeutic views of Abu Ali ibn Sina / K.Yu. Yuldashev. Tashkent.

MUKHAMEDOVA ZAMIRA MUKHAMEDZHANOVNA

Department of Social and Humanitarian Sciences

Tashkent State Dental Institute, Uzbekistan

Email: muhamedova_zamir@mail.ru

UMIRZAKOVA NARGIZA AKMALOVNA

Department of Social and Humanitarian Sciences

Tashkent State Dental Institute, Uzbekistan

E-mail: naumirzakova@mail.ru

MAKHMUDOVA AZIZA NUGMANOVNA

Department of Social and Humanitarian Sciences

Samarkand Medical Institute, Uzbekistan

E-mail: rustamovamaxmudova@bk.ru

*Corresponding author: muhamedova_zamir@mail.ru 